\title{
Penerapan Metode Analytical Hierarchy Process Untuk Menentukan Program Keahlian Di SMK Model Patriot IV Ciawigebang Kuningan
}

\author{
Siti Maesyaroh ${ }^{1}$ \\ ${ }^{1}$ Fakultas Ilmu Komputer Universitas Kuningan \\ E-mail: $*^{1}$ siti.maesyaroh@ uniku.ac.id
}

\begin{abstract}
Abstrak
Pemilihan program keahlian bagi siswa SMK diperkenalkan sebagai upaya untuk mengarahkan siswa terhadap bakat dan minat serta kemampuan siswa tersebut. Tetapi sebagian besar siswa masih kebingunan ketika diberikan pilihan program keahlian. Bahkan siswa memilih program keahlian dengan cara ikut-ikutan dengan teman-temannya. Sistem pendukung keputusan merupakan suatu media untuk memberikan kemudahan bagi siswa untuk mengambil sebuah keputusan dalam memilih program keahlian. Supaya hasil pemilohan program keahlian yang dilakukan siswa melalui sistem lebih obyektif dan berkeadilan diusulkan menggunakan metode Analytical Hierarchy Process (AHP). Desain penelitian ini berupa perancangan sistem pemilihan program keahlian dibuat dengan berbasis web. Dengan sistem ini, diharapkan mampu memudahkan siswa untuk menentukan program keahlian.
\end{abstract}

Kata Kunci - Sistem Pendukung Keputusan, Analytical Hierarchy Process, Program Keahlian, Web.

\begin{abstract}
The selection of department for vocational students is introduced as an effort to guide students towards the talents, interests and abilities of students. But most students are still confused when they are given a choice of department. Even students choose a program followingh their friends'. Decision support system is a medium to make easy for students to make a decision in choosing a department. In order that the results of the piloting of the expertise program carried out by students objectively and equitable system, it is proposed to use the Analytical Hierarchy Process (AHP) method. The design of this study is in the form of designing a system for selecting departments made with web-based. With this system, it is expected to facilitate students to determine their department.
\end{abstract}

Keywords - Decision Support System, Analytical Hierarchy Process, Department, Web

\section{PENDAHULUAN}

Sekolah kejuruan khususnya SMK Model Patriot IV Ciawigebang memerlukan sistem pendukung keputusan untuk menentukan program keahlian yang diminati siswa seperti Teknik Komputer dan Jaringan (TKJ), Otomatisasi dan Tata Kelola Perkantoran (OTKP), Perbankan Keuangan Mikro (PKM), Teknik dan Bisnis Sepeda Motor (TBSM), dan Asisten Keperawatan (AKP). Program keahlian bertujuan agar siswa lebih mudah dalam memilih jurusan di Perguruan Tinggi atau mengarah ke profesi mereka. Tetapi program keahlian bagi siswa SMK tidak selalu sesuai dengan kemampuan, bakat, minat, dan prestasi akademiknya. Hal ini dikarenakan siswa merasa kebingungan ketika diberikan pilihan program keahlian. Bahkan sebagian besar siswa memilih salah satu jurusan dengan cara ikut-ikutan dengan teman-temannya.

Oleh karena itu, untuk mengatasi berbagai permasalahan yang telah 
JURNAL BUFFER INFORMATIKA

Volume 5 Nomor 1, April 2019

dikemukakan tersebut maka dibutuhkan teknologi komputerisasi untuk pengambilan keputusan dalam memilih program keahlian di SMK Model Patriot IV Ciawigebang. Supaya hasil pemilihan jurusan yang dilakukan siswa SMK melalui sistem lebih obyektif dan berkeadilan diusulkan dengan menggunakan metode Analytical Hierarchy Process (AHP).

Metode AHP ini membantu memecahkan persoalan yang kompleks dengan menstruktur suatu hirarki kriteria, pihak yang berkepentingan, hasil dan dengan menarik berbagai pertimbangan guna mengembangkan bobot atau prioritas (Turban dan Peng Liang, 2005).

Dengan adanya sistem ini diharapkan mampu membantu siswa SMK dalam memilih program keahlian sesuai dengan bakat, minat dan nilai akademik siswa”.

\section{METODE PENELITIAN}

Diagram alir dari metode penelitian yang dilakukan dapat dilihat pada Gambar 1.

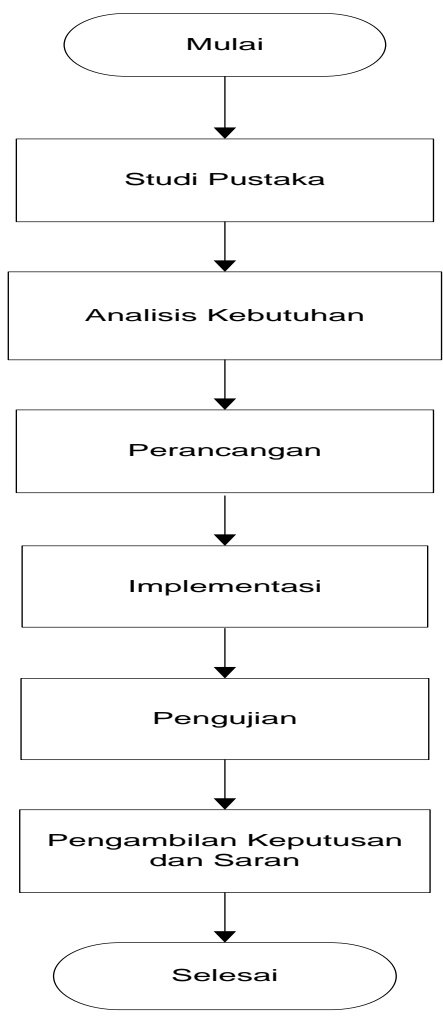

Gambar 1. Diagram Alir Metode Penelitian
p-ISSN : 2527-4856, e-ISSN : 2614-5413

https://journal.uniku.ac.id/index.php/buffer

\subsection{Prototype Model}

Prototype merupakan salah satu metode pengembangan perangkat lunak yang banyak digunakan. Dengan metode prototyping ini pengembang dan pelanggan dapat saling berinteraksi selama proses pembuatan sistem.

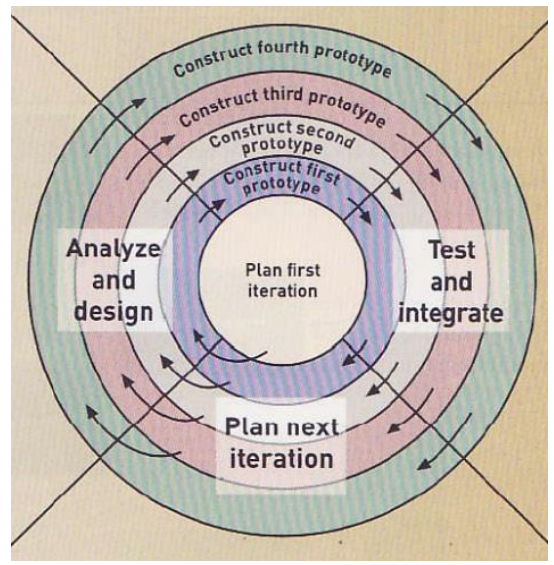

Gambar 2. Tahapan Prototype Model (Pressman, Roger S, 2007).

a. Pengumpulan Kebutuhan

Pelanggan dan pengembang bersamasama mendefinisikan format seluruh perangkat lunak, mengidentifikasikan seluruh kebutuhan dan garis besar system yang akan dibuat. Pada tahp ini ditentukan sampel data yang akan diolah beserta variabel yang akan diamati.

b. Merancang dan membangun prototyping

Pada tahap ini, dilakukan perancangan menggunakan UML dan pembuatan prototype sistem. Prototype dibuat sesuai dengan kebutuhan sistem yang telah didefinisikan sebelumnya. Untuk pengolahan data diterapkan metode Analytical Hierarchy Process (AHP) ke dalam sistem. Tahapan dalam metode Analytical Hierarchy Process (AHP) dapat dilihat pada Gambar 2. 
JURNAL BUFFER INFORMATIKA

Volume 5 Nomor 1, April 2019

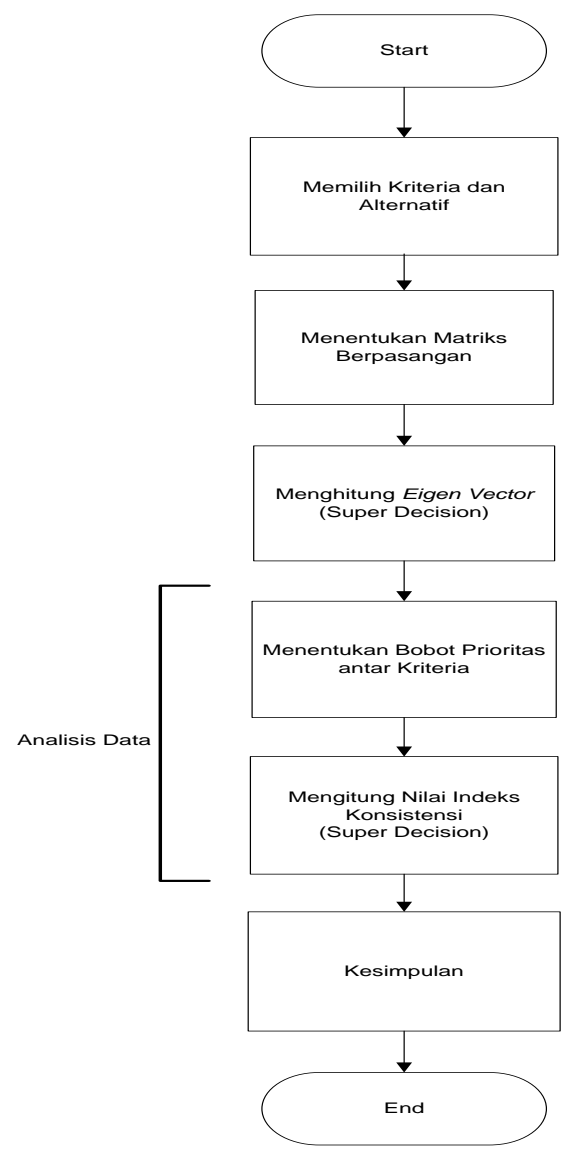

Gambar 3. Tahapan Metode Analytical Hierarchy Process (AHP)

c. Implementasi (Implementation)

Sistem yang telah menjadi perangkat lunak siap pakai, diuji terlebih dahulu menggunakan pengujian Black Box dan White Box. Dimana pada pengujian Black Box dilakukan pengujian kesesuaian Antara input dan output, sedangkan pengujian White Box dilakukan dengan pengujian fungsi program. Pengujian dilakukan oleh pengguna untuk mengevaluasi prototype yang dihasilkan jika terdapat kekurangan dari kebutuhan pengguna atau pun adanya pengembangan maka prototype akan diperbaiki kembali.

\subsubsection{Teknik Pengumpulan Data}

Teknik pengumpulan data yang digunakan dalam penelitian ini adalah :

\section{a. Metode Wawancara}

Metode wawancara merupakan cara langsung untuk mendapatkan informasi yang akurat dan dapat dipakai sebagai
p-ISSN : 2527-4856, e-ISSN : 2614-5413

https://journal.uniku.ac.id/index.php/buffer

landasan pertama untuk melakukan penelitian yang lebih dalam.Hasil dari data tersebut dapat digunakan sebagai gambaran dari masalah-masalah yang diteliti. Adapun wawancara yang dilakukan dalam penelitian ini dilakukan dengan melakukan sesi tanya jawab kepada bagian yang menangani pemilihan program keahlian siswa SMK Model Patriot IV Ciawigebang.

b. Metode Obsevasi

Observasi merupakan pengamatan secara langsung mengenai kegiatan pemilihan program keahlian siswa SMK Model Patriot IV Ciawigebang agar diperoleh data mengenai sistem yang sedang berjalan.

c. Metode Studi Literatur /Pustaka

Studi Pustaka merupakan cara pengumpulan data yang dilakukan dengan mencari landasan teori dari berbagai buku maupun jurnal-jurnal penelitian yang terkait dengan penelitian dan mempelajari proses pemilihan program keahlian siswa SMK Model Patriot IV Ciawigebang. Daftar literature tersebut terlampir dalam daftar pustaka.

\subsection{2. $U M L$}

Menurut Nugroho (2005:16), UML (unifield Modeling Language) adalah metode pemodelan sistem / perangkat lunak secara visual.

a. Diagram Kelas

Diagram ini memperlihatkan himpunan kelas-kelas, antarmuka, kolaborasi-kolaborasi, serta relasi-relasi. Diagram ini umum dijumpai pada pemodelan system berorientasi objek.

b. Diagram Objek

Diagram ini memperlihatkan objekobjek serta relasi-relasi antar objek. Diagram objek memperlihatkan instansiasi statis dari segala sesuatu yang dijumpai pada diagram kelas.

c. Use case diagram

Diagram ini memperlihatkan himpunan use case dan aktor-aktor (suatu jenis khusus dari kelas). Diagram ini terutama sangat penting untuk mengorganisasi dan memodelkan perilaku dari suatu sistem yang dibutuhkan.

d. Sequence Diagram 
JURNAL BUFFER INFORMATIKA

Volume 5 Nomor 1, April 2019

Interaksi yang menekankan pada pengiriman pesan (message) dalam suatu waktu tertentu

e. Activity Diagram

Diagram aktivitas ini adalah tipe khusus dari digram state yang memperlihatkan aliran dari suatu aktifitas ke aktifitas lainnya dalam suatu system. Diagram ini terutama penting dalam pemodelan fungsi-fungsi.

\section{HASIL DAN PEMBAHASAN}

Hasil dari penelitian ini meliputi hasil rekapitulasi nilai siswa yang ditunjukkan pada matriks berpasangan yang dihasilkan dari hasil rekapitulasi nilai UN, nilai raport, nilai tes wawancara dan nilai tes fisik yang diperoleh dari masing-masing siswa.

1. Hasil Penelitian

a. Hasil Rekapitulasi

Hasil rekapitulasi nilai siswa yang digunakan sebagai sampel data berjumlah 15 data untuk dilakukan proses AHP sehingga mempunyai cukup banyak tabel yang dihasilkan maka dalam bab ini hanya akan diuraikan untuk kriteria terhadap kluster Goal. Tabel 1 menunjukkan data siswa SMK Model Patriot IV Ciawigebang

Tabel 1. Data Nilai Siswa SMP

\begin{tabular}{|l|l|c|c|}
\hline No. & \multicolumn{1}{|c|}{ Nama } & $\begin{array}{c}\text { Nilai } \\
\text { UN }\end{array}$ & $\begin{array}{c}\text { Nilai } \\
\text { Raport }\end{array}$ \\
\hline 1. & $\begin{array}{l}\text { Aam } \\
\text { Nur'afiah }\end{array}$ & 56.5 & 79 \\
\hline 2. & Ade Ikbal & 42.375 & 76.5 \\
\hline 3. & $\begin{array}{l}\text { Anisa } \\
\text { Sofyan }\end{array}$ & 60.3 & 84.1 \\
\hline 4. & $\begin{array}{l}\text { Dadan } \\
\text { Suhendar }\end{array}$ & 52.1 & 76.8 \\
\hline 5. & $\begin{array}{l}\text { Diana } \\
\text { Rosdiana }\end{array}$ & 54.25 & 83.7 \\
\hline 6. & $\begin{array}{l}\text { Febian } \\
\text { Ramdani }\end{array}$ & 34 & 76 \\
\hline 7. & $\begin{array}{l}\text { Gilang } \\
\text { Hadiwa }\end{array}$ & 37.25 & 77.29 \\
\hline 8. & Milla Safitri & 77.87 & 78 \\
\hline 9. & $\begin{array}{l}\text { Muhamad } \\
\text { Rifqi }\end{array}$ & 40.75 & 79.5 \\
\hline 10. & Nadia & 45.8 & 83.2 \\
\hline
\end{tabular}

p-ISSN : 2527-4856, e-ISSN : 2614-5413

https://journal.uniku.ac.id/index.php/buffer

\begin{tabular}{|c|l|c|c|}
\hline & Septiani & & \\
\hline 11. & $\begin{array}{l}\text { Naya } \\
\text { Nurhaimah }\end{array}$ & 47.8 & 80.8 \\
\hline 12. & Nurjanah & 55.5 & 85 \\
\hline 13. & Seli Serliana & 52.5 & 81.14 \\
\hline 14. & Sindi Ardita & 61.5 & 82.6 \\
\hline 15. & $\begin{array}{l}\text { Suci } \\
\text { Atikaningsih }\end{array}$ & 51.375 & 86 \\
\hline
\end{tabular}

Tabel 2 menunjukkan hasil rekapitulasi data siswa dengan membandingkan antar kriteria. Sedangkan bentuk matriks berpasangan yang dihasilkan dari tabel tersebut untuk kriteria yang berbentuk matrik pada tabel 3 .

Tabel 2. Hasil Rekapitulasi Data Siswa

\begin{tabular}{|c|c|c|c|c|c|c|c|}
\hline \multirow[b]{2}{*}{ No } & \multirow[b]{2}{*}{ Nama } & \multicolumn{6}{|c|}{ Perbandingan Kriteria } \\
\hline & & $\begin{array}{l}\text { Rap } \\
\text { or- } \\
\text { UN }\end{array}$ & $\begin{array}{l}\text { Raport- } \\
\text { Wawanc } \\
\text { ara }\end{array}$ & $\begin{array}{l}\text { Rapor- } \\
\text { Fisik }\end{array}$ & $\begin{array}{l}\text { UN- } \\
\text { Wawa } \\
\text { ncara }\end{array}$ & $\begin{array}{l}\text { UN- } \\
\text { Fisik }\end{array}$ & $\begin{array}{l}\text { Wawa } \\
\text { ncara- } \\
\text { Fisik }\end{array}$ \\
\hline 1. & $\begin{array}{l}\text { Aam } \\
\text { Nur'afiah }\end{array}$ & 2 & 1 & 1 & 2 & 2 & 2 \\
\hline 2. & Ade Ikbal & 2 & 2 & 2 & 2 & 3 & 2 \\
\hline 3. & Anisa Sofyan & 2 & 1 & 1 & 2 & 1 & 2 \\
\hline 4. & $\begin{array}{l}\text { Dadan } \\
\text { Suhendar }\end{array}$ & 2 & 2 & 2 & 2 & 2 & 1 \\
\hline 5. & $\begin{array}{l}\text { Diana } \\
\text { Rosdiana }\end{array}$ & 2 & 1 & 1 & 2 & 2 & 2 \\
\hline 6. & $\begin{array}{l}\text { Febian } \\
\text { Ramdani }\end{array}$ & 3 & 2 & 2 & 3 & 3 & 1 \\
\hline 7. & $\begin{array}{l}\text { Gilang } \\
\text { Hadiwa }\end{array}$ & 2 & 1 & 2 & 3 & 3 & 2 \\
\hline 8. & Milla Safitri & 1 & 1 & 1 & 2 & 1 & 2 \\
\hline 9. & $\begin{array}{l}\text { Muhamad } \\
\text { Rifqi }\end{array}$ & 2 & 1 & 2 & 2 & 2 & 2 \\
\hline 10. & $\begin{array}{l}\text { Nadia } \\
\text { Septiani }\end{array}$ & 2 & 1 & 1 & 2 & 2 & 1 \\
\hline 11. & $\begin{array}{l}\text { Naya } \\
\text { Nurhaimah }\end{array}$ & 2 & 1 & 1 & 2 & 2 & 1 \\
\hline 12. & Nurjanah & 2 & 1 & 1 & 2 & 2 & 1 \\
\hline 13. & Seli Serliana & 2 & 1 & 2 & 2 & 2 & 2 \\
\hline 14. & Sindi Ardita & 1 & 1 & 2 & 2 & 1 & 2 \\
\hline 15. & $\begin{array}{l}\text { Suci } \\
\text { Atikaningsih }\end{array}$ & 2 & 1 & 1 & 2 & 2 & 1 \\
\hline & Rata-rata & 1.9 & 1.1 & 1.4 & 2.1 & 1.9 & 1.5 \\
\hline
\end{tabular}

Hasil rekapitulasi data dari tabel diatas dibuat dalam matriks berpasangan.

Tabel 3. Matriks Berpasangan Untuk Kriteria

\begin{tabular}{|c|c|c|c|c|c|}
\hline No. & $\begin{array}{c}\text { Perbandingan } \\
\text { Kriteria }\end{array}$ & Raport & UN & $\begin{array}{c}\text { Wawa } \\
\text { ncara }\end{array}$ & Fisik \\
\hline 1 & Raport & 1 & 1.9 & 1.1 & 1.4 \\
\hline 2 & UN & 0,52 & 1 & 2.1 & 1.9 \\
\hline 3 & Wawancara & 0,9 & 0,47 & 1 & 1.5 \\
\hline 4 & Fisik & 0,7 & 0,52 & 0,66 & 1 \\
\hline
\end{tabular}


JURNAL BUFFER INFORMATIKA

Volume 5 Nomor 1, April 2019
p-ISSN : 2527-4856, e-ISSN : 2614-5413

https://journal.uniku.ac.id/index.php/buffer

b. Hasil Perhitungan Eigen Vektor

Bentuk matriks berpasangan yang dihasilkan melalui rekapitulasi data siswa selanjutnya akan dihitung nilai eigen vektornya untuk mendapatkan nilai bobot rangking masing-masing parameter yang telah ditentukan dalam masing-masing kriteria.

\begin{tabular}{|l|l|c|c|c|c|c|}
\hline 7. & Gilang Hadiwa & $30 \%$ & $32 \%$ & $17 \%$ & $9 \%$ & $12 \%$ \\
\hline 8. & Milla Safitri & $9 \%$ & $20 \%$ & $32 \%$ & $25 \%$ & $14 \%$ \\
\hline 9. & Muhamad Rifqi & $45 \%$ & $19 \%$ & $11 \%$ & $12 \%$ & $13 \%$ \\
\hline 10. & Nadia Septiani & $22 \%$ & $16 \%$ & $13 \%$ & $28 \%$ & $21 \%$ \\
\hline 11. & $\begin{array}{l}\text { Naya } \\
\text { Nurhaimah }\end{array}$ & $28 \%$ & $9 \%$ & $30 \%$ & $12 \%$ & $21 \%$ \\
\hline 12. & Nurjanah & $23 \%$ & $17 \%$ & $20 \%$ & $29 \%$ & $21 \%$ \\
\hline 13. & Seli Serliana & $30 \%$ & $12 \%$ & $12 \%$ & $39 \%$ & $7 \%$ \\
\hline 14. & Sindi Ardita & $23 \%$ & $25 \%$ & $20 \%$ & $14 \%$ & $28 \%$ \\
\hline 15. & $\begin{array}{l}\text { Suci } \\
\text { Atikaningsih }\end{array}$ & $28 \%$ & $6 \%$ & $17 \%$ & $30 \%$ & $19 \%$ \\
\hline
\end{tabular}

Tabel 4. Nilai Eigen Untuk Alternatif

2. Hasil Pembahasan

Pembahasan yang akan dijelaskan

\begin{tabular}{|c|c|c|c|c|c|c|}
\hline No & Alternatif & OTKP & TKJ & TBSM & PKM & AKP dam Nilasidigen \\
\hline 1 & OTKP & 1 & 2.3 & 1.94 & 2.1 & $2.1^{\text {yatg }}$ g.jgambarkan \\
\hline 2 & TKJ & 0.43 & 1 & 1.6 & 1.8 & 1.7berdasarkangta \\
\hline 3 & TBSM & 0.51 & 0.62 & 1 & 1.8 & Keba.tushan Non Fungsional \\
\hline 4 & PKM & 0.47 & 0.55 & 0.55 & 1 & 1.8Untuk Relbratuhan non fungsional \\
\hline 5 & AKP & 0.47 & 0.58 & 0.62 & 0.55 & .10115 \\
\hline
\end{tabular}

c. Indeks Konsistensi

Nilai indeks konsistensi (CI) bertujuan untuk mengetahui konsistensi jawaban yang akan berpengaruh pada tingkat akurasi dari hasil yang diperoleh.

Untuk nilai Consistency Index dapat diperoleh dari perhitungan seperti berikut :

$\mathrm{CI}=\left(\lambda_{\max }-\mathrm{n}\right) /(\mathrm{n}-1) ; \mathrm{n}:$ banyaknya alternatif

$$
\begin{aligned}
& \mathrm{CI}=((5.08+5.05+5.16+5.14+ \\
& 5.13) / 5)-5 /(5-1) \\
& \mathrm{CI}=(5.112-5) / 4 \\
& \mathrm{CI}=0.028
\end{aligned}
$$

Untuk $\mathrm{n}$ bernilai 5, maka nilai RI adalah 0,90. Dengan demikian, nilai CR pada alternatif adalah 0,028/ 0,90 =0,031. Karena nilai CR $<0,100$ maka preferensi penilaian adalah konsisten atau di dalam membandingkan tingkat kesalahannya $3,1 \%$.

Setelah semua siswa dilakukan perhitungan menggunakan metode AHP maka dapat diketahui data rekomendasi jurusan.

Tabel 5. Rekomendasi Jurusan Berdasarkan Metode AHP

\begin{tabular}{|l|l|c|c|c|c|c|}
\hline \multirow{2}{*}{ No } & \multirow{2}{*}{ Nama } & \multicolumn{5}{|c|}{ Perbandingan Alternatif } \\
\cline { 3 - 7 } & & OTKP & TKJ & TBSM & PKM & AKP \\
\hline 1. & Aam Nur'afiah & $32 \%$ & $19 \%$ & $17 \%$ & $18 \%$ & $14 \%$ \\
\hline 2. & Ade Ikbal & $42 \%$ & $19 \%$ & $13 \%$ & $15 \%$ & $11 \%$ \\
\hline 3. & Anisa Sofyan & $45 \%$ & $14 \%$ & $14 \%$ & $13 \%$ & $14 \%$ \\
\hline 4. & $\begin{array}{l}\text { Dadan } \\
\text { Suhendar }\end{array}$ & $39 \%$ & $30 \%$ & $14 \%$ & $7.3 \%$ & $9.5 \%$ \\
\hline 5. & Diana Rosdiana & $30 \%$ & $26 \%$ & $17 \%$ & $13 \%$ & $14 \%$ \\
\hline 6. & Febian Ramdani & $28 \%$ & $26 \%$ & $18 \%$ & $16 \%$ & $12 \%$ \\
\hline
\end{tabular}

\begin{tabular}{|c|c|c|c|}
\hline No & Kebutuhan & $\begin{array}{l}\text { Komputer } \\
\text { Server }\end{array}$ & $\begin{array}{c}\text { Komputer } \\
\text { Client }\end{array}$ \\
\hline 1. & Hardware & $\begin{array}{ll}\text { a. } & \text { PC Dual } \\
\text { b. } & \text { RAM } \\
\text { bb } \\
\text { c. }\end{array}$ & $\begin{array}{ll}\text { a. } & \text { PC Dual } \\
\text { b. } & \text { RAre } \\
& \text { Gb } \\
\text { c. } & \text { HDD } \\
& 120 \mathrm{~Gb} \\
\text { d. Mouse } \\
\text { e. Keyboar } \\
\text { f. } \\
\text { f. Monitor } \\
\text { g. } \text { Lcd 14' } \\
\text { grinter }\end{array}$ \\
\hline 2. & Software & $\begin{array}{ll}\text { a. } & \text { Microsof } \\
\mathrm{t} \\
\text { Window } \\
\mathrm{s} 7 \\
\end{array}$ & $\begin{array}{ll}\text { a. } & \text { Micrsosf } \\
\mathrm{t} \\
\text { Window } \\
\text { s } 7\end{array}$ \\
\hline
\end{tabular}

Tabel 6. Kebutuhan Pembangunan Aplikasi

\begin{tabular}{|ll|ll|}
\hline \multicolumn{2}{|c|}{ Hardware } & \multicolumn{2}{c|}{ Software } \\
\hline a. & PC & a. & Microsoft \\
& Notebook & Windows 10 \\
& Processor & b. & Adobe \\
& Intel & & Dreamweaver \\
& Celeron & & CS5 \\
b. & RAM 4 Gb & c. & XAMPP 1.8.4 \\
c. & HDD 120 & d. & Google Chrome \\
& Gb & & \\
d. & Mouse & & \\
e. & Printer & & \\
f. & Flash Disk & & \\
\hline
\end{tabular}

Tabel 7. Kebutuhan Implementasi Aplikasi 
JURNAL BUFFER INFORMATIKA

Volume 5 Nomor 1, April 2019

\begin{tabular}{|c|c|c|c|}
\hline & & $\begin{array}{ll}\text { b. } & \text { Xampp } \\
& 1.8 .4 \\
\text { c. } & \text { Google } \\
& \text { Chrome }\end{array}$ & $\begin{array}{ll}\text { b. } & \text { Google } \\
& \text { Chrome }\end{array}$ \\
\hline
\end{tabular}

b. Merancang dan Membangun

Prototyping

Perancangan sistem yang dibangun dalam penelitian ini menggunakan UML.

1. Diagram Use Case

Diagram use case digunakan untuk mengetahui fungsi apa saja yang ada di dalam sebuah sistem informasi dan siapa saja yang berhak menggunakan fungsi tersebut. Berikut ini adalah diagram use case dari aplikasi penentuan program keahlian di SMK.

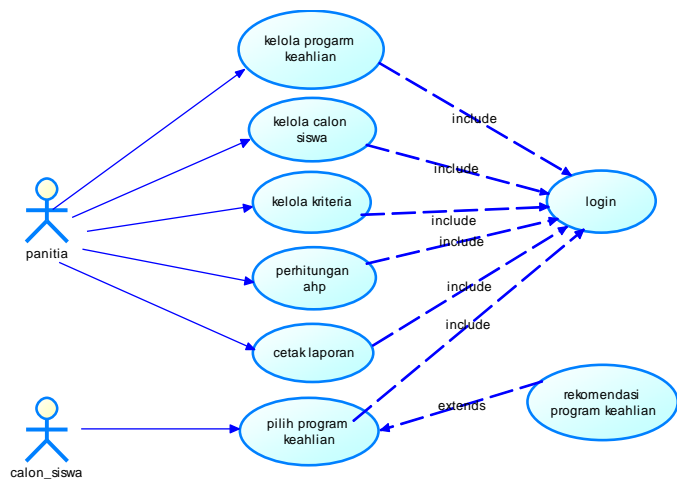

Gambar 4. Diagram Use Case

\section{Skenario Use Case}

Tabel 8. Skenario Use Case Pilih Program Keahlian.

\begin{tabular}{|l|l|}
\hline Use Case ID & UC004 \\
\hline Use Case Name & Data Utama \\
\hline Deskripsi Singkat & $\begin{array}{l}\text { Aktor memilih program keahlian } \\
\text { dan melihat rekomendasi program } \\
\text { keahlian berdasarkan perhitungan } \\
\text { AHP }\end{array}$ \\
\hline Aktor & Calon Siswa Baru \\
\hline Pre Condition & $\begin{array}{l}\text { Aktor telah melakukan login } \\
\text { terlebih dahulu }\end{array}$ \\
\hline Post Condition & $\begin{array}{l}\text { Sistem dapat menjalankan } \\
\text { perintah CRUD (insert, view, } \\
\text { update, delete) data utama dari } \\
\text { actor ke database dan kembali ke } \\
\text { halaman awal untuk } \\
\text { menampilkan data keseluruhan. }\end{array}$ \\
\hline
\end{tabular}

p-ISSN : 2527-4856, e-ISSN : 2614-5413

https://journal.uniku.ac.id/index.php/buffer

\begin{tabular}{|c|c|}
\hline Aksi Aktor & Reaksi Sistem \\
\hline $\begin{array}{l}\text { Actor memilih menu } \\
\text { untuk pemilihan } \\
\text { program keahlian }\end{array}$ & 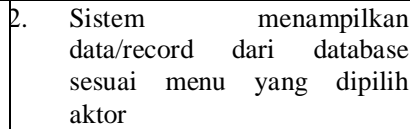 \\
\hline $\begin{array}{l}\text { Aktor melakukan } \\
\text { manipulasi data } \\
\text { (tambah, update, dan } \\
\text { hapus data) dari data } \\
\text { pilih program } \\
\text { keahlian }\end{array}$ & $\begin{array}{l}\text { Sistem melakukan perintah } \\
\text { manipulasi data ke database } \\
\text { sesuai dengan yang dipilih } \\
\text { aktor }\end{array}$ \\
\hline & $\begin{array}{l}\text { 5. Sistem kembali ke halaman } \\
\text { awal untuk menampilkan data } \\
\text { keseluruhan }\end{array}$ \\
\hline \multicolumn{2}{|r|}{ Alternate Flow } \\
\hline $\begin{array}{ll}\text { 1. } & \text { Aktor tidak } \\
\text { memasukkan data }\end{array}$ & $\begin{array}{l}\text { 2. Sistem menampilkan pesan } \\
\text { error dan kembali ke halaman } \\
\text { awal untuk menampilkan } \\
\text { data. }\end{array}$ \\
\hline
\end{tabular}

3. Diagram Activity

Berikut ini adalah salah satu diagram aktivitas dari aplikasi penentuan program keahlian di SMK.

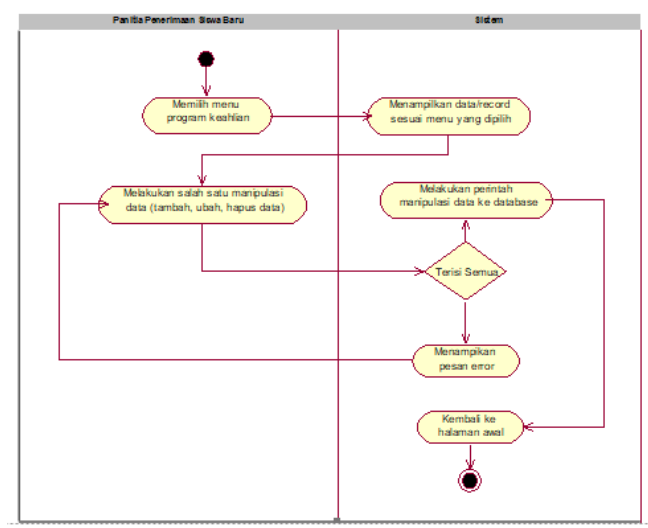

Gambar 5. Activity Diagram Kelola Program Keahlian

\section{Class Diagram}

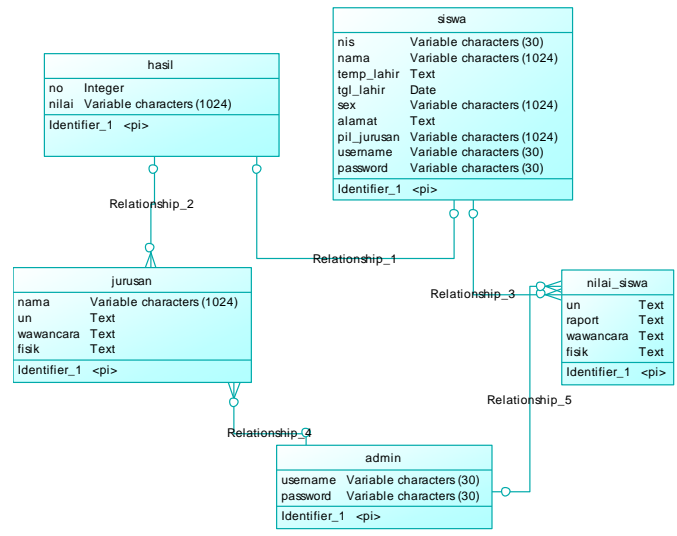

Gambar 6. Class Diagram 
JURNAL BUFFER INFORMATIKA

Volume 5 Nomor 1, April 2019

c. Implementasi

1. Login

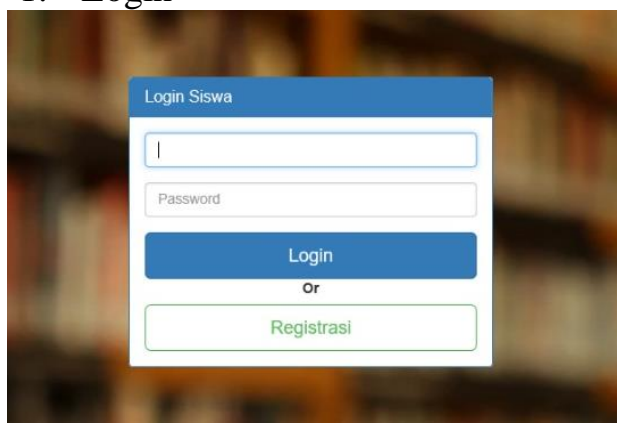

Gambar 7. Form Login

2. Halaman Rekap Jurusan

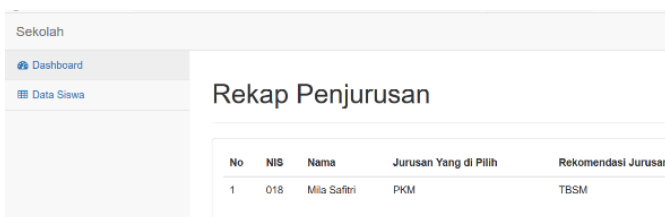

Gambar 8. Halaman Rekap Jurusan

\section{Halaman Data Calon Siswa}

\section{Data Calon siswa}

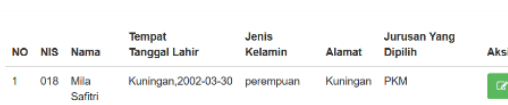

Gambar 9. Halaman Data Calon Siswa

4. Halaman Admin

Data Penilaian

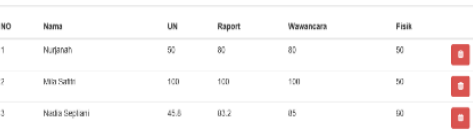

Gambar 10. Halaman Admin

\section{Form Input Nilai Siswa}

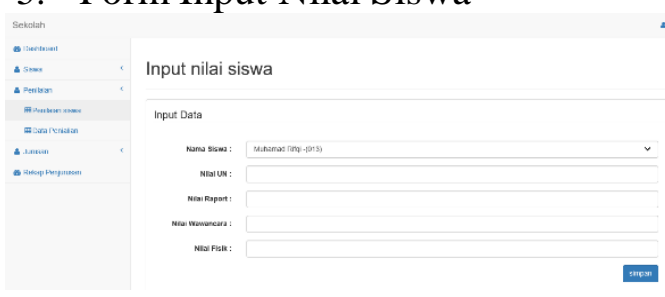

Gambar 11. Form Input Nilai Siswa
p-ISSN : 2527-4856, e-ISSN : 2614-5413

https://journal.uniku.ac.id/index.php/buffer

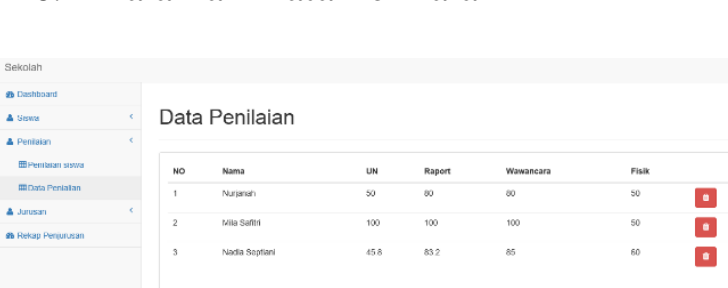

Gambar 12. Halaman Data Penilaian

\section{d. Pengujian}

Sebelum aplikasi dapat digunakan, maka harus dilakukan pengujian terlebih dahulu. Hal ini mengarahkan untuk mencari semua kemungkinan kesalahan dan memastikan bahwa masukan yang dibatasi akan memberikan hasil yang sesuai dengan yang dibutuhkan.

1. Pengujian Blackbox

Tabel 9. Pengujian Blackbox

\begin{tabular}{|c|c|c|c|c|}
\hline No. & Pengujian & $\begin{array}{l}\text { Hasil yang } \\
\text { diharapkan }\end{array}$ & $\begin{array}{l}\text { Hasil } \\
\text { Pengujian }\end{array}$ & Validasi \\
\hline \multirow[t]{2}{*}{1.} & \multirow[t]{2}{*}{$\begin{array}{l}\text { Login (User } \\
\text { memasukkan } \\
\text { username } \\
\text { dan } \\
\text { password) }\end{array}$} & $\begin{array}{l}\text { Jika username } \\
\text { dan password } \\
\text { benar maka } \\
\text { akan } \\
\text { menampilkan } \\
\text { halaman } \\
\text { utama admin }\end{array}$ & $\begin{array}{l}\text { Menampil } \\
\text { kan } \\
\text { halaman } \\
\text { utama } \\
\text { admin }\end{array}$ & valid \\
\hline & & $\begin{array}{l}\text { Jika username } \\
\text { dan password } \\
\text { salah maka } \\
\text { akan } \\
\text { menampilkan } \\
\text { pesan dan user } \\
\text { diperintahkan } \\
\text { untuk } \\
\text { menginputkan } \\
\text { kembali }\end{array}$ & $\begin{array}{l}\text { Menampil } \\
\text { kan pesan } \\
\text { "Username } \\
\text { dan } \\
\text { Password } \\
\text { salah" dan } \\
\text { menampilk } \\
\text { an halaman } \\
\text { login }\end{array}$ & valid \\
\hline 2. & $\begin{array}{l}\text { Penilaian } \\
\text { (user } \\
\text { memilih } \\
\text { menu } \\
\text { Penilaian) }\end{array}$ & $\begin{array}{l}\text { Menampilkan } \\
\text { halaman yang } \\
\text { berisi sub } \\
\text { menu } \\
\text { Penilaian } \\
\text { Siswa dan } \\
\text { Data Penilaian }\end{array}$ & $\begin{array}{l}\text { Menampil } \\
\text { kan } \\
\text { halaman } \\
\text { yang berisi } \\
\text { sub menu } \\
\text { Penialaian } \\
\text { Siswa dan } \\
\text { Data } \\
\text { Penilaian }\end{array}$ & valid \\
\hline 3 & $\begin{array}{l}\text { User } \\
\text { memilih } \\
\text { menu } \\
\text { Jurusan }\end{array}$ & $\begin{array}{lr}\text { Menampilkan } \\
\text { halaman } & \text { yang } \\
\text { berisi } & \text { sub } \\
\text { menu } & \text { Data } \\
\text { Jurusan } & \text { dan } \\
\end{array}$ & $\begin{array}{l}\text { Menampil } \\
\text { kan } \\
\text { halaman } \\
\text { yang berisi } \\
\text { sub menu }\end{array}$ & valid \\
\hline
\end{tabular}


JURNAL BUFFER INFORMATIKA

Volume 5 Nomor 1, April 2019
p-ISSN : 2527-4856, e-ISSN : 2614-5413

https://journal.uniku.ac.id/index.php/buffer

\begin{tabular}{|l|l|l|l|l|}
\hline & $\begin{array}{l}\text { Input Data } \\
\text { Jurusan }\end{array}$ & Penilaian & \\
& Data & \\
& & & \\
& & darusan Input & \\
Data & \\
& & & Jurusan & \\
\hline
\end{tabular}

2. Pengujian Whitebox

Tabel 10. Kode Program Login

\begin{tabular}{|c|c|}
\hline No. & Kode Program \\
\hline 1. & include "../config/koneksi.php"; \\
\hline 2. & $\begin{array}{l}\text { \$username =\$_POST['username']; } \\
\text { \$password } \\
\text { =md5(\$_POST['password']); } \\
\text { \$query = mysqli_query(\$con,"select * } \\
\text { from admin rere } \\
\text { username='\$username' } \\
\text { password='\$password'"); } \\
\text { \$num = mysqli_num_rows(\$query); }\end{array}$ \\
\hline 3. & if $($ \$num $>0)\{$ \\
\hline 4. & $\begin{array}{l}\text { \$query2 = mysqli_query(\$con,"select } \\
* \quad \text { from admin } \\
\text { usernmae='\$username' } \\
\text { password='\$password'"); } \\
\text { \$admin } \\
\text { mysqli_fetch_array(\$query); } \\
\text { session_start(); }\end{array}$ \\
\hline & $\begin{array}{l}\text { \$_SESSION['admin']=\$admin['nama']; } \\
\text { echo "<script> }\end{array}$ \\
\hline & $\begin{array}{l}\text { window.location='../index.php'; } \\
</ \text { script }>\text { "; }\end{array}$ \\
\hline 5. & \} \\
\hline 6. & $\begin{array}{l}\text { else }\{ \\
\text { echo "<script> } \\
\text { alert('Username atau Password } \\
\text { salah'); } \\
\quad \text { window.location='../index.php'; } \\
</ \text { script }>\text { "; }\end{array}$ \\
\hline 7. & \\
\hline
\end{tabular}

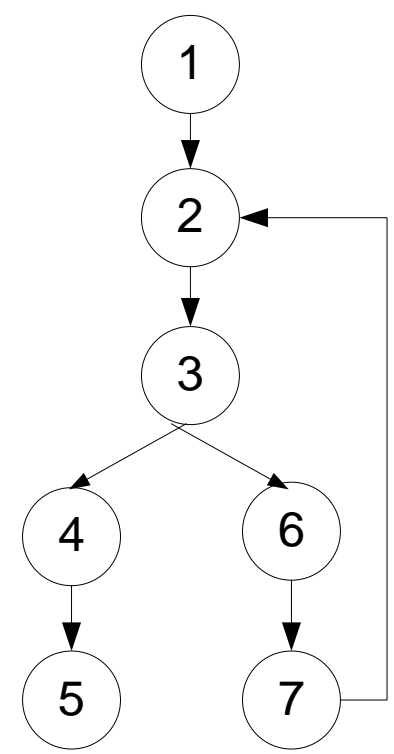

Gambar 13. Graph Pengujian White Box Login

$$
\begin{aligned}
\mathrm{G} & =\mathrm{N}-\mathrm{E}+2 \\
& =7-7+2 \\
& =2
\end{aligned}
$$

\section{No Jalur/Path \\ 1. 1-2-3-4-5 \\ 2. $1-2-3-6-7-2$}

\section{KESIMPULAN}

Berdasarkan hasil penelitian dan pembahasan maka penyelesaian untuk pokok permasalahan yang telah dirumuskan dapat disampaikan kesimpulannya sebagai berikut :

a. Sistem pendukung keputusan dengan menggunakan metode AHP dapat digunakan untuk menyelesaikan permasalahan dalam memilih program keahlian di SMK Model Patriot IV Ciawigebang.

b. Dengan adanya sistem pemilihan program keahlian berbasis web dapat memudahkan siswa SMK Model Patriot IV Ciawigebang dalam memilih program keahlian sesuai dengan kemampuan, bakat, minat, dan prestasi akademik.

c. Hasil dari ini dapat memberikan rekomendasi bagi siswa untuk memilih program keahlian. 
JURNAL BUFFER INFORMATIKA

Volume 5 Nomor 1, April 2019

\section{SARAN}

Adapun saran yang diperlukan untuk pengembangan penelitian ini adalah :

a. Perlu membandingkan hasilnya dengan menggunakan metode lain selain AHP, agar dapat ditentukan dengan mudah kelemahannya.

b. Perlu adanya penambahan fasilitas untuk tes secara online agar lebih mempermudah user.

\section{UCAPAN TERIMA KASIH}

Penulis mengucapkan terima kasih kepada LPPM Universitas Kuningan yang telah memberi dukungan financial terhadap penelitian ini.

Serta penulis mengucapakan terima kasih kepada semua pihak SMK Model Patriot IV Ciawigebang Kuningan khususnya Panitia Penerimaan Siswa Baru yang telah membantu dalam pengumpulan data penelitian.

\section{DAFTAR PUSTAKA}

Adriyendi \& Melia, Yeni. (2013, March). DSS using AHP in Selection of Lecturer. International Journal of Advanced Science and Technology.

A, Nugroho. 2010. Rekayasa Perangkat Lunak Menggunakan UML dan Java. Andi: Yogyakarta.

Kusrini. 2007. Konsep dan Aplikasi Sistem Pendukung Keputusan. Yogyakarta : Andi.

A, Nugroho. 2010. Rekayasa Perangkat Lunak Menggunakan UML dan Java. Andi: Yogyakarta

Kusumadewi, S., Hartati, S., Harjoko, A., \& Wardoyo, R. (2006). Fuzzy Multi-Atrribute Decision Making (Fuzzy MADM). Yogyakarta : Garaha Ilmu.
p-ISSN : 2527-4856, e-ISSN : 2614-5413

https://journal.uniku.ac.id/index.php/buffer

Putra, Nasution, (2014). Sistem Pendukung Keputusan Penambahan Program Studi Dengan Metode Analytical Hierarchy Process (AHP). Majalah Ilmiah Informasi dan Teknologi Ilmiah, 2339-20X.

Rima, Dewi. (2011). Sistem Pendukung Keputusan Evaluasi Kinerja Dosen Berbasis Analytical Hierarchy Process (AHP). Jurnal Manajemen Sistem Informasi dan Teknologi.

Soepardi, A., Puryani, Chaeron, M., Anggraini, I., (2012). Penentuan Kriteria Pemilihan Strategi Sistem Manufaktur Menggunakan Analytical Hierarchy Process. Jurnal Teknik Industri, 107-114.

http://download.portalgaruda.org/article . php? article $=395674 \&$ val $=7863 \&$ title $=$ Sistem\%20Pendukung $\% 20 \mathrm{~K}$ eputusan\%20Untuk\%20Menentuk an\%20Program $\% 20$ Keahlian $\% 20$ di\%20SMK\%20Syubbanul $\% 20 \mathrm{~W}$ athon\%20Magelang diakses 10 Februari 2018.

http://wayanfm.lecture.ub.ac.id/files/ 2014/04/FPSPK_F_D-2013-2014Ganjil-.pdf diakses 20 Februari 2018. 